LIMA, SF; JESUS, AA; VENDRUSCOLO, EP; OLIVEIRA, TR; ANDRADE, MGO; SIMON, CA. 2019. Development and production of sweet corn applied with biostimulant as seed treatment. Horticultura Brasileira 38: 94-100. DOI - http://dx.doi.org/10.1590/S0102-053620200115

\title{
Development and production of sweet corn applied with biostimulant as seed treatment
}

\author{
Sebastião F Lima ${ }^{1} \mathbb{D}$; Anderson A Jesus ${ }^{1} \mathbb{L}$; Eduardo P Vendruscolo² ${ }^{\mathbb{L}}$; Tabata Raissa Oliveira ${ }^{3} \mathbb{D}$; Maria \\ Gabriela O Andrade ${ }^{4 \mathbb{D}}$; Cátia Aparecida Simon ${ }^{5 \mathbb{D}}$
}

${ }^{1}$ Fundação Universidade Federal de Mato Grosso do Sul (UFMS), Chapadão do Sul-MS, Brasil; sebastiao.lima@ufms.br; anderson.jesus@ ufms.br; ${ }^{2}$ Universidade Estadual de Mato Grosso do Sul (UEMS), Cassilândia-MS, Brasil; eduardopradi@gmail.com; ${ }^{3}$ Nufarm, Chapadão do Sul-MS, Brasil; tabata.raissa@hotmail.com; ${ }^{4}$ Universidade Estadual Paulista (UNESP), Botucatu-SP, Brasil; gabriela13andrade@hotmail. com; ${ }^{5}$ Universidade de São Paulo (USP), Piracicaba-SP, Brasil; catiasimon@usp.br

\begin{abstract}
Sweet corn has potential to increase farmer's income. Thus, biostimulants may contribute to increase productivity of sweet corn, being indicated and used in various crops. The objective of this study was to evaluate the effects of applying biostimulant on sweet corn crops and to establish the ideal dose aiming to increase the crop's agronomic characteristics. The experiment was installed in the municipality of Chapadão do Sul-MS and was conducted from November 15, 2012 to February 19, 2013. Treatments were composed of eight biostimulant doses $(0.0,4.0,8.0,12.0,16.0,20.0,24.0$ and $28.0 \mathrm{~mL} \mathrm{~kg}^{-1}$ of seeds), arranged in a randomized complete block design with four replicates. The responses of the variables to the best dose of biostimulant were $12.4,15.3,13.7,12.4,15.7,16.4,15.4$ and $12.5 \mathrm{~mL} \mathrm{~kg}^{-1}$, respectively for plant height, first ear insertion height, stem diameter, final population, number of ears per hectare, ear mass with and without straw and ear index. Considering that the ear with straw is the source of economic return to the producer, the dose of $16.4 \mathrm{~mL} \mathrm{~kg}^{-1}$ is the best indication in this condition.
\end{abstract}

Keywords: Zea mays convar. saccharata var. rugosa (sweet corn), phytohormones, growth regulators.

\section{RESUMO}

Desenvolvimento e produção do milho doce tratado com bioestimulante

O milho doce é uma cultura com potencial para aumentar a renda de propriedades agrícolas. Dessa forma, os bioestimulantes podem contribuir para o aumento da produtividade do milho doce, sendo indicados e utilizados em diversas culturas. $\mathrm{O}$ objetivo deste estudo foi avaliar os efeitos da aplicação do bioestimulante para a cultura do milho doce e estabelecer a dose ideal para aumentar as características agronômicas da cultura. $\mathrm{O}$ experimento foi instalado no município de Chapadão do Sul-MS, e foi realizado de 15 de novembro de 2012 a 19 de fevereiro de 2013. Os tratamentos foram compostos por oito doses de bioestimulantes $(0,0,4,0,8,0,12,0,16,0,20,0,24,0$ e 28,0 $\mathrm{mL} \mathrm{kg}^{-1}$ de sementes), dispostas em delineamento em blocos ao acaso, com quatro repetições. As respostas das variáveis à melhor dose de bioestimulante foram 12,4, 15,3, 13,7, 12,4, 15,7, 16,4, 15,4 e 12,5 $\mathrm{mL} \mathrm{kg}{ }^{-1}$, respectivamente para altura da planta, altura da inserção da primeira espiga, diâmetro do colmo, população final, número de espigas por hectare, massa de espigas com e sem palha e índice de espigas. Considerando que a espiga com palha é a fonte de retorno econômico ao produtor, a dose de $16,4 \mathrm{~mL} \mathrm{~kg}^{-1}$ é a melhor indicação nessa condição.

Palavras-chave: Zea mays convar. saccharata var. rugosa, fitormônios, reguladores de crescimento.

\section{Received on September 10, 2019; accepted on January 24, 2020}

$\mathrm{B}$ razil is the third largest producer of corn in the world, only after China and the United States (FAO, 2018). This productive potential implies that the country also has the necessary characteristics for producing other types of corn such as popcorn and those directed to in natura consumption or for industrialization. So, sweet corn (Zea mays convar. saccharata var. rugosa) is largely cultivated for the canned products industry, almost exclusively for human consumption. This characteristic attributed it to be classified as a special cultivation (Oliveira Junior et al., 2006).

In terms of land, the world area cultivated with sweet corn is approximately 1.04 million hectares. The United States of America is the country with the largest productive area of about 100,000 hectares and an average yield of $8.09 \mathrm{t} \mathrm{ha}^{-1}$ (USDA, 2017). The Brazilian scenario does not present great popularity for sweet corn, although edaphoclimatic conditions contribute to a productivity of more than $13.00 \mathrm{t} \mathrm{ha}^{-1}$ (Luz et al., 2014), the technological cultivation conditions maintain productivity below those observed in countries such as the USA, with around $17.17 \mathrm{t} \mathrm{ha}^{-1}$ (FAO, 2018).

Provision of appropriate management forms allows the country to target higher productivity (Souza et al., 2015, 2016) and the insertion of this product into large consumer markets. In addition, this scenario contributes to this species being inserted in rural properties as an alternative for 
production diversification, while its cultivation presents a good profit margin to the producer (Jesus et al., 2016).

In addition to the necessary improvements in cultural management, we seek differentiated strategies that enable the producer to enter the market in a competitive way with higher quality products, but without incurring productive losses. In this context, introducing biostimulant products into production systems is seen as an opportunity, and although there is no specific legislation to this group of products, research is continuously being conducted to improve the performance of different crops such as popcorn (Oliveira et al., 2016) and sweet corn itself (Cunha et al., 2016).

By definition, biostimulants are mixtures of one or more growth regulators with other compounds of different chemical nature, such as mineral salts (Castro \& Pereira, 2008), which promote hormonal balance and stimulate root growth (Silva et al., 2008) due to action mechanisms, especially when using products composed by growth regulators (Taiz et al., 2017).

In the context of costs related to the production system, it is observed that pre-planting treatment with biostimulating products is a procedure that barely burdens rural producers (Jesus et al., 2016). This is mainly due to the low concentrations of plant regulators necessary to incur changes in the physiological plant system (Taiz et al., 2017). In this way, small increases in productivity are sufficient to cover the investments for acquiring this technology.

In addition, biostimulant action can promote vegetative and reproductive performance when it is implemented in the initial stages due to the developmental characteristics of corn crops, improving the crop's nutritional conditions by developing its root system (Cunha et al., 2016) and increasing cell division and expansion rates (Taiz et al., 2017), provided that optimal doses of the product are implemented. Good nutritional and physiological conditions are determinants for the crop, considering that determining the productive and vegetative potential happens until the V3 phenological stage (Magalhães \& Durães, 2006).

Despite all positive expectations with biostimulants and the good results obtained from the germination of the seeds to the growth in height of plants, observed by Avila et al. (2008) in the soybean crop, Ferreira et al. (2007) warn that biostimulants cannot always be favorable, because they depend on several factors such as the plant species, the composition of the product used, among others.

In light of the above, the objective of the study was to evaluate the effects of applying biostimulant in sweet corn cultivation and the proper dose establishment aiming to increase the crop's biometric and productive characteristics.

\section{MATERIAL AND METHODS}

The experiment was installed in the municipality of Chapadão do SulMS, (186'18"S, 52 37'28'"W, 813 $\mathrm{m}$ altitude) and was conducted from November 15, 2012 to February 19, 2013. According to Köppen, the climate is tropical humid (Aw), with a rainy season in summer and dry in winter, and an average annual rainfall of 1850 $\mathrm{mm}$ with average annual temperatures varying from $13^{\circ} \mathrm{C}$ to $28^{\circ} \mathrm{C}$, while the experimental area's soil is classified as Oxysoil.

The experimental design was a randomized block with four replications, totaling 32 plots. Each plot was composed of five lines, five meters in length, spaced at $0.45 \mathrm{~m}$ between rows and 0.30 between plants, with a final population of 74,000 plants ha-1, featuring a dense sowing for sweet corn. The three central plot lines were considered useful area.

Treatments were composed of eight commercial biostimulant doses of Stimulate $(0.0 ; 4.0,8.0,12.0,16.0$, $20.0,24.0$ and $28.0 \mathrm{~mL} \mathrm{~kg}^{-1}$ seeds), composed of three plant regulators in the following formulation: $0.009 \%$ kinetin (cytokinin), $0.005 \%$ gibberellic acid (gibberiline) and $0.005 \%$ indolebutyric acid (auxin).

Sweet corn GNZ 2004 hybrid was used for sowing. Seeds were treated with fungicide $(8.5 \%$ Thiabendazole + $35 \%$ Thiran) at $200 \mathrm{~g}$ per $100 \mathrm{~kg}$ seeds.

The biostimulant was applied using a graduated pipette directly onto the seeds packed in transparent plastic bags with $2.0 \mathrm{~kg}$ capacity. After application the whole amount was vigorously stirred for two minutes, aiming to standardize the treatments on the seed mass.

Seeds were sown manually, being sowing and top dressing based on a soil analysis presenting the following characteristics: $8.0 \mathrm{mg} \mathrm{dm}^{-3} \mathrm{P}$ (mehlich ${ }^{-1}$ ); $31.1 \mathrm{~g} \mathrm{dm}^{-3}$ M.O.; $4.8 \mathrm{pH}\left(\mathrm{CaCl}_{2}\right) ; \mathrm{K}^{+}$, $\mathrm{Ca}^{2+}, \mathrm{Mg}^{+2}$ and $\mathrm{H}+\mathrm{Al}=0.38 ; 2.80$; 1.10 and $4.9 \mathrm{cmol}_{\mathrm{c}} \mathrm{dm}^{-3}$, respectively, and $46.6 \%$ base saturation. Liming was performed 60 days before sowing, using dolomitic limestone, 75\% PRNT, to raise the base saturation to $60 \%$ (Souza \& Lobato, 2004). Weeds, pests and diseases were controlled according to the plant breeding recommendation for cultivating corn. Fertilization for sowing consisted of $30 \mathrm{~kg} \mathrm{~N} \mathrm{ha}^{-1}$, $120 \mathrm{~kg} \mathrm{P}_{2} \mathrm{O}_{5} \mathrm{ha}^{-1}$ and $60 \mathrm{~kg} \mathrm{~K}_{2} \mathrm{O} \mathrm{ha} \mathrm{h}^{-1}$, using urea, simple superphosphate and potassium chloride fertilizers. For top dressing, $180 \mathrm{~kg} \mathrm{~N}^{-1}$ and $90 \mathrm{~kg} \mathrm{~K}_{2} \mathrm{O}$ ha $^{-1}$ were applied, divided into two applications, when the crop presented 4-6 leaves and 8-10 leaves, respectively, using urea and chloride fertilizers. Sowing and top dressing were based on recommendations of Souza \& Lobato (2004).

The evaluated characteristics were plant height $(\mathrm{PH})$, first ear insertion height (EH) and stem diameter (SD). Height was determined from the ground level to the tassel insertion node and to the first ear for $\mathrm{PH}$ and $\mathrm{EH}$, respectively. Stem diameter was measured with a tape measure in the second internode from the plant base.

All ears of the plot areas were harvested manually. The harvest time was visually determined when green ears and kernels were in a milky stadium. The final plant population (POP) was also determined at this time, counting the plants in the useful plot area, also considering the bedded and/or broken plants, transforming the population obtained per hectare.

The number of ears (NE) per area 
was obtained during harvest, counting all ears in the useful lines of each plot. All harvested ears had their masses measured with and without husks after harvest. In order to obtain the ear index (EI), plants were counted in the useful lines of each plot (number of plants per plot $=$ NPP) and the total number of ears per plot (NEP) at the time of harvest. The index is generated by the relation between these factors (EI $=\mathrm{NPP} / \mathrm{NEP})$.

Regression analysis was used to verify the fit of polynomial models for dependent variables as a function of the Stimulate doses applied to the seeds at a 5\% probability level.

\section{RESULTS AND DISCUSSION}

The biostimulant doses interfered in the characteristics of plant height, first ear insertion height and stem diameter, final plant population, number of ears per hectare, mass of ears with and without husks per hectare, and the ear index for sweet corn cultivation (Figures 1 and 2).

There was an increase in the mean height of sweet corn plants up to the dose of $12.4 \mathrm{~mL} \mathrm{~kg}^{-1}$, reaching $234.6 \mathrm{~cm}$. Compared to the control treatment this maximum dose obtained increase plant height in $4.24 \%$. Similar behavior was verified for the first ear insertion height, where a dose of $15.3 \mathrm{~mL} \mathrm{~kg}^{-1}$ enabled the first ear to reach the maximum height of $141.1 \mathrm{~cm}$. Higher biostimulant doses impaired the first ear insertion height; however, the insertion height reached a minimum of $124.6 \mathrm{~cm}$ without biostimulant application (Figure 1A).

In relation to stem diameter, the dose of $13.7 \mathrm{~mL} \mathrm{~kg}^{-1}$ applied to the sweet corn seeds provided stems with larger diameters, reaching a value of 24.3 $\mathrm{mm}$. This maximum dose estimated culminated in an increase of $4.89 \%$ on the stem diameter (Figure 1B). Higher yield of corn ears are also positively linked to stem diameter (Table 1), since it means higher photoassimilate storage capacity, which are fundamental for developing the grains (Kappes et al., 2011).

Stem diameter is a highly relevant factor during the sweet corn plant cycle. In testing 85 different corn genotypes at five sites, Gomes et al. (2010) observed that bedding resistance is linked to the genotype and the environmental conditions in which the cultivation is conducted. Thus, the increase in stem diameter observed in the present study may indicate that these same treatments have the potential to reduce bedding risk.

There was also a positive correlation between other evaluated characteristics (Table 1). This fact implies the need to maintain better values for these characteristics in the plant in order to obtain higher yields. In addition to the direct effect of stem diameter on yield, other characteristics greatly affect this same variable, such as ear insertion height and number of ears per area, which in turn have a high correlation with other characteristics, generating an indirect effect.
The effects on plant vegetative development are related to the phytohormone action present in the biostimulant's composition. Cytokinin and auxin phytonutrients act on cell differentiation and on phloem and xylem differentiation, respectively, and both act on cell division and stretching these structures, especially in the early development stages (Taiz et al., 2017). This promotion of rapid development in the early stages may improve plant establishment and plant growth in later stages, since the plant development point is below the soil surface up to the V3 stage, becoming vulnerable to abiotic factors such as low temperatures, lack or excess of water (Magalhães \& Durães, 2006).

Gibberellins are also important for the establishment, development and reproduction of plants. This phytohormone is involved in seed germination, stem elongation, leaf expansion, pollen maturation and flowering induction, and the occurrence of levels below adequate levels may result in dwarfism and other physiological deficiencies (Davière \& Achard, 2013). Its exogenous application can alleviate the deleterious effects of the environment, allowing the plants to maintain vegetative and reproductive development even in adverse conditions (Hamayun et al., 2010; Sakata et al., 2014; Khan et al., 2015), resulting an appropriate growth.

The results corroborate studies on different species of commercial interest and sweet corn, which relate increases

Table 1. Estimates of Pearson's linear correlation coefficients, between characteristics of sweet corn plants under different biostimulant doses $\left(\mathrm{mL} \mathrm{kg}^{-1}\right)$ applied to the seeds. Chapadão do Sul, UFMS, 2013.

\begin{tabular}{lcccccccc}
\hline Characteristics & HP & HE & SD & POP & NE & MEW & EI & MEN \\
\hline HP & 1 & - & - & - & - & - & - & - \\
HE & $0.779^{* *}$ & 1 & - & - & - & - & - & - \\
SD & $0.665^{* *}$ & $0.628^{* *}$ & 1 & - & - & - & - & - \\
POP & $0.914^{* *}$ & $0.795^{* *}$ & $0.657^{* *}$ & 1 & - & - & - & - \\
NE & $0.362^{*}$ & $0.722^{* *}$ & $0.319 \mathrm{~ns}$ & $0.475^{* *}$ & 1 & - & - & - \\
MEW & $0.646^{* *}$ & $0.781^{* *}$ & $0.400^{* *}$ & $0.647^{* *}$ & $0.511^{* *}$ & 1 & - & - \\
EI & $0.607^{* *}$ & $0.477^{* *}$ & $0.346 \mathrm{~ns}$ & $0.435^{*}$ & $0.267 \mathrm{~ns}$ & $0.300 \mathrm{~ns}$ & 1 & - \\
MEN & $0.424^{*}$ & $0.664^{* *}$ & $0.570^{* *}$ & $0.475^{* *}$ & $0.752^{* *}$ & $0.395 \mathrm{~ns}$ & $0.325 \mathrm{~ns}$ & 1 \\
\hline
\end{tabular}

$\mathrm{HP}=$ plant height; $\mathrm{HE}=$ first ear insertion height; $\mathrm{SD}=$ stem diameter; $\mathrm{POP}=$ final plant population; $\mathrm{NE}=$ number of ears per $\mathrm{plot}$; $\mathrm{MEW}=$ mass of ears with husk; $\mathrm{EI}=$ ear index; $\mathrm{MEN}=$ mass of ears without husk; *** and ns $=$ significant at $1 \%, 5 \%$ probability and non-significant by t-test. 
of the biometric characteristics observed in the plant's initial development with the physiological effect provided by the biostimulant. For cucumber, tomato and lettuce crops, Vendruscolo et al. (2016) observed increases in the plant height, leaf number, leaf size and shoot dry matter accumulation of the seedlings when the seeds were maintained for 30 minutes in solution concentrations of 7.0 $\mathrm{mL} \mathrm{L}^{-1}, 4.92 \mathrm{~mL} \mathrm{~L}^{-1}$ and higher than 3.33 $\mathrm{mL} \mathrm{L}^{-1}$, respectively, before sowing. On rice cultivation there are gains in shoot development by applying doses up to $10 \mathrm{~mL} \mathrm{~kg}^{-1}$ to seeds (Rodrigues et al., 2015), and for sweet corn increases in height, stem diameter, leaf area, stem dry matter, leaf dry matter and root dry matter were observed in applying doses up to $20 \mathrm{~mL} \mathrm{~kg}^{-1}$ on seeds (Cunha et al., 2016).

The highest population of sweet corn plants was obtained at a dose of $12.4 \mathrm{~mL}$ $\mathrm{kg}^{-1}$, reaching 73,673 plants per hectare, an increase of $13.37 \%$ (8,688 plants) in the final plant population comparing to the control treatment. Barbieri et al. (2005) verified that the sweet corn ear yield increased linearly with the increase of plant population. The authors also reported that sweet corn practically does not have productive plasticity, not compensating for the productivity when there is a smaller number of plants per area. In this way, the importance of correctly treating seeds using products with biostimulating action is perceived with the view to maintain the plant stand, and consequently good productivity.

There was a decline in the plant population from the dose of $12.4 \mathrm{~mL}$ $\mathrm{kg}^{-1}$ to the lowest final plant population observed with a biostimulant dose of 28 $\mathrm{mL} \mathrm{kg}^{-1}$ with 59,993 plants per hectare, inferring in $22.8 \%$ variation between these two extreme populations. In addition, when the dose of $28 \mathrm{~mL} \mathrm{~kg}^{-1}$ was applied to the sweet corn seeds a loss of 4,992 plants or $7.68 \%$ was observed on the final plant population.

The highest amount of ears per hectare was reached with the dose of $15.7 \mathrm{~mL} \mathrm{~kg}^{-1}$, reaching 61,457 ears in a population of 73,061 plants $\mathrm{ha}^{-1}$. This reduction in ears is probably due to the high population density used. On the other hand, higher doses, until $28 \mathrm{~mL} \mathrm{~kg}^{-1}$, caused reduced ear production, but the minimum production was reached without biostimulant application, reflecting the lower plant population obtained in this treatment, applying the dose of $15.7 \mathrm{~mL} \mathrm{~kg}^{-1}$. The variation between the extremes in ear production was $18.6 \%$ (Figure $2 \mathrm{~A}$ ). The results again refer to the adequacy of the biostimulant doses employed so that the plant stand is adequate, since the plant stand and number of ears are intrinsically linked characteristics.

For the variable mass of ears with husk, the highest productivity per hectare was reached using the dose of $16.4 \mathrm{~mL} \mathrm{~kg}^{-1}$, reaching $15,813 \mathrm{~kg}$ $\mathrm{ha}^{-1}$, while higher doses reduced ear yield. However, the lowest value was obtained without applying biostimulant, $13,558 \mathrm{~kg}$, representing a variation of $16.6 \%$, which is $2,255 \mathrm{~kg}$ per hectare.
These results may be related to the cell multiplication action promoted by the phytohormones present in the biostimulant during initial development stage (Taiz et al., 2017) of sweet corn plants, since determining the maximum number of kernels is established in stage V3 (Magalhães \& Durães, 2006). In this sense, Dourado Neto et al. (2014) observed a similar situation in which application of Stimulate $10 \mathrm{X}$ $\left(1.0 ; 1.5 ; 2.0 \mathrm{~mL} \mathrm{~kg}^{-1}\right)$ in corn seeds positively influenced the number of rows and number of kernels per ear when compared to the control treatment without biostimulant application.

The cellular differentiation and division during the plants vegetative development is significantly affected by the flow of intracellular auxin. This flow allows the maintenance of adequate levels of this phytohormone which is

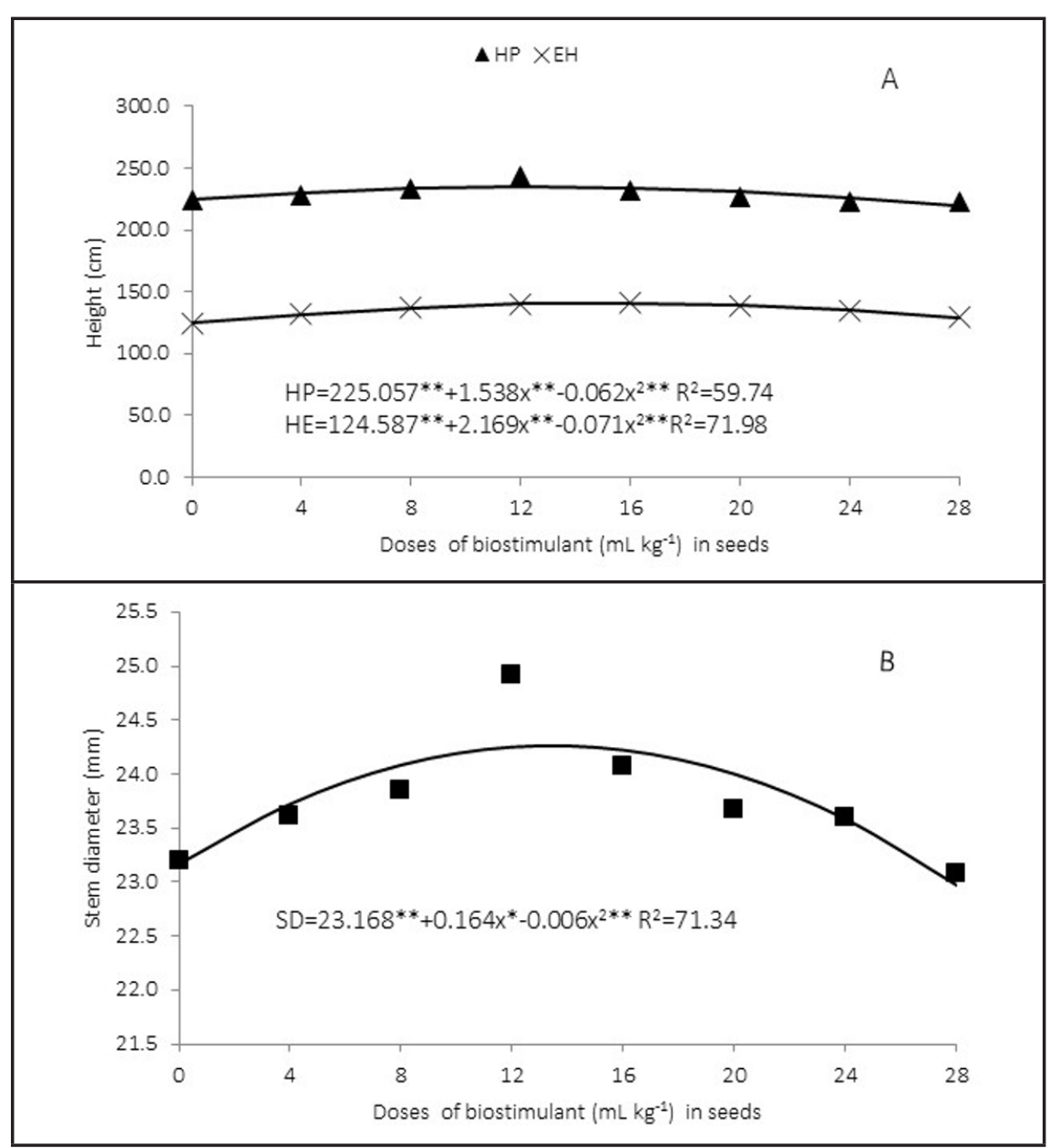

Figure 1. Plant height (HP), first ear insertion height (EH) (A) and stem diameter (B) of sweet corn plants under different biostimulant doses $\left(\mathrm{mL} \mathrm{kg}^{-1}\right)$ applied to the seeds. Chapadão do Sul, UFMS, 2013. 
responsible for numerous developmental responses (Schaller et al., 2015). In addition, the interaction between auxin and cytokinin governs virtually all aspects of apical root meristem development and, consequently, the growth of the root system (Schaller et al., 2015), influencing the absorption of water and nutrients.

Considering the dose of $12.4 \mathrm{~mL}$ $\mathrm{kg}^{-1}$, where the largest plant population was reached, for the number of ears per hectare and mass of ears with straw, the values obtained were $15,678 \mathrm{~kg}$ and 61,039 ears, respectively. These values represent a negative difference

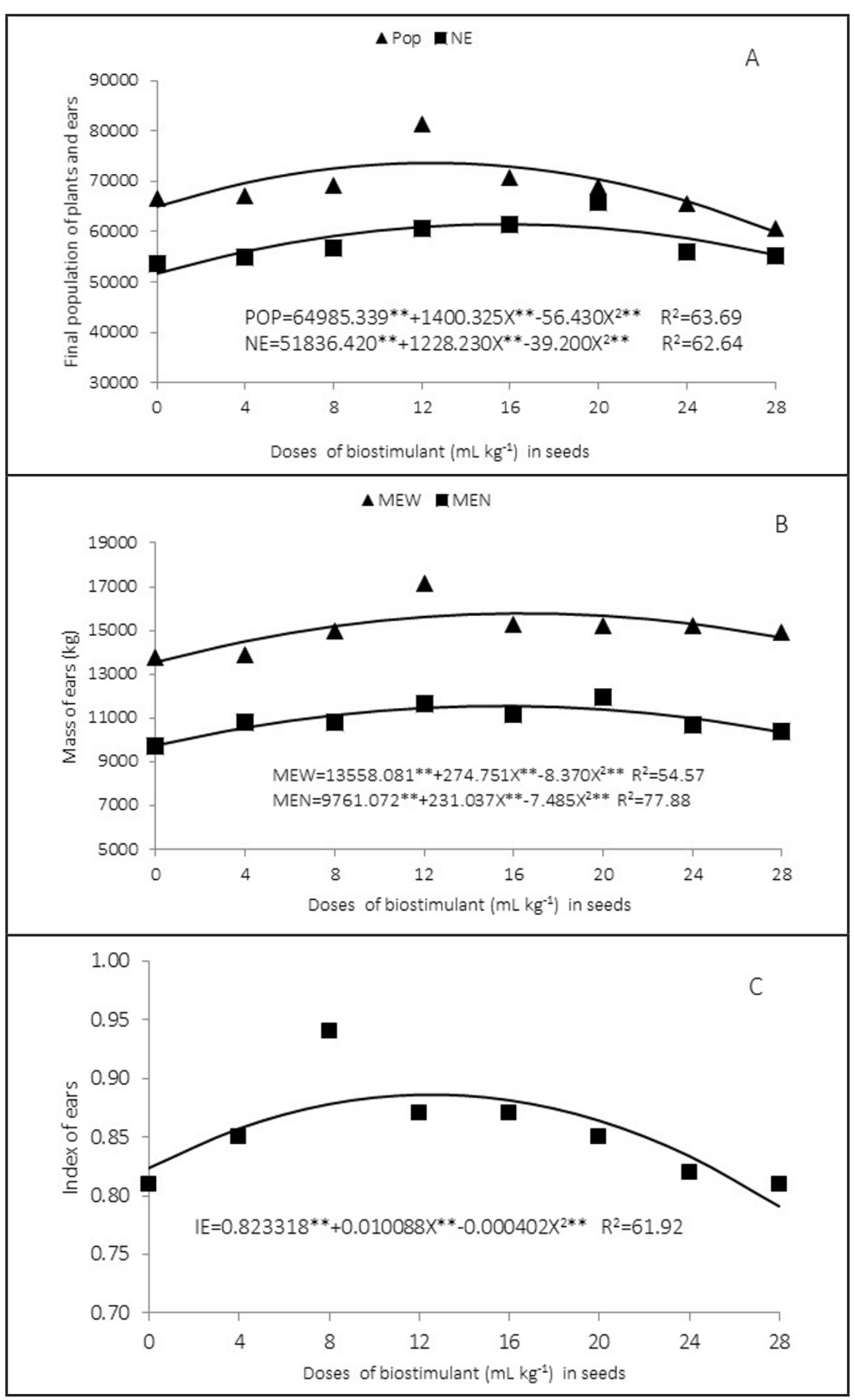

Figure 2. Final plant population (Pop) (A), number of ears (NE), mass of ears with husk (MEW), mass of ears without husk (MEN) (B) and ear index (C) of sweet corn under different biostimulant doses $\left(\mathrm{mL} \mathrm{kg}^{-1}\right)$ applied to the seeds. Chapadão do Sul, UFMS, 2013. of $135 \mathrm{~kg}$ and 418 ears, when compared to the doses of 15.7 and $16.4 \mathrm{~mL} \mathrm{~kg}^{-1}$, which promoted the highest number of ears per plant and mass of ears with straw. Despite the small difference, this represents a value of about $\mathrm{R} \$ 100$ per hectare.

The highest yields of ears were reached using biostimulant doses close to the best doses for stem development, characterizing a possible relationship between these variables. This occurs because a better stem structure may reflect increased kernel quality and yield through efficient use and translocation of carbohydrates to the kernels, since these events are negatively influenced by factors such as plant bedding (Pariz et al., 2011).

Positive correlation was observed between most of the studied variables. Only among the variables index of ear with stem diameter, number of ears per hectare, ear mass with straw and ear mass without straw, between ear mass with straw and without straw and between number of ears per hectare and stem diameter no significance was observed for the correlations (Table 1). The mass of ears with straw, which is the main economic return variable for the producer, was positively correlated with plant growth characteristics, in addition to the final plant population and number of ears per hectare. This is a strong indication of the importance of seeking to improve other characteristics in the plant or crop in order to achieve higher yields.

There is recommended that ears with husk mass is greater than $12 \mathrm{t} \mathrm{ha}^{-1}$ for corn destined for in natura consumption (Pereira Filho et al., 2003). In this context, all treatments reached higher productivity than this indication, with a general average of $15,061 \mathrm{~kg} \mathrm{ha}^{-1}$. Even in the absence of Stimulate application, ears with husk productivity was above the recommendation of $13,558 \mathrm{~kg} \mathrm{ha}^{-1}$. This higher value was expected because of the highest plant density used $(74,000$ plants ha-1), compared to the other study cited above $\left(50,000\right.$ plants $\left.\mathrm{ha}^{-1}\right)$.

For yield of ears without husks, biostimulant application of $15.4 \mathrm{~mL}$ $\mathrm{kg}^{-1}$ culminated in $11,444 \mathrm{~kg} \mathrm{ha}^{-1}$, a value higher than that obtained by 
Albuquerque et al. (2008) who obtained an average of $10,195 \mathrm{~kg} \mathrm{ha}^{-1}$ of ears without straw with the same hybrid and a population of 50,000 plants ha ${ }^{-1}$. The production behavior observed for the ears without husk was similar to that obtained for ears with husk, with reduced productivity at doses above $15.4 \mathrm{~mL} \mathrm{~kg}^{-1}$ and in the absence of biostimulant (Figure 2B).

The highest ear index was reached with the biostimulant dose of $12.5 \mathrm{~mL}$ $\mathrm{kg}^{-1}$, reaching 0.89 . The lowest ear index was obtained at the highest applied dose $\left(28 \mathrm{~mL} \mathrm{~kg}^{-1}\right)$, at which time the index reached 0.79 , representing a variation of $12.7 \%$ (Figure 2C). Higher ear indices result in better utilization of the planted area, since they indicate that it is possible to obtain higher yields with an equal or smaller number of plants.

The results are once again linked to the phytohormone action during the early germination and plantlet establishment. The production characteristics (defined during the V3 stage) are dependent on the nutritional, physiological and environmental conditions in which the crop is found (Magalhães \& Durães, 2006). Thus, in addition to the direct physiological effect on cell division and expansion maximized by the presence of the hormone compounds present in the product (Taiz et al., 2017), the effects on root development both in size and in accumulating matter (Cunha et al., 2016) contribute to soil exploitation by the plant, increases water and nutrient absorption capacity, and consequently improves vegetative and reproductive development conditions.

The negative effects observed in this work when applying high doses of biostimulant may be reflexes from the action of indolbutyric acid (IBA) and kinetin. When there are occurrences of levels above the optimal auxin and cytokinin levels in plant tissues, even though these phytohormones are part of the complex activity of cell division, there may be a marked effect on organ growth inhibition such as the stem, leaves and the ears (Taiz et al., 2017).

Specifically, in the case of auxins the deleterious effects are triggered by the formation of reactive forms of oxygen and, from these, the occurrence of oxidative degradation, senescence and cell death are observed (Pazmiño et al., 2012). This effect is widely used in agricultural production systems for weed control (Grossman, 2010). In this way, the definition of optimum doses becomes essential in order to avoid productive and economic losses.

When used rationally, phytohormone-based biostimulants may favor economic gains. It is observed that their use in different cultivated species results in increased productivity, as carrot (Ávila et al., 2016), corn (Martins et al., 2016) and soybean (Bertolin et al., 2010). In this sense, sweet corn is also included, for which there was a small share of the costs with the application of biostimulants and a significant increase in the monetary return (Jesus et al., 2016).

The financial return that can be obtained with the use of biostimulant can be simulated considering the current product price at $\mathrm{R} \$ 90$ per liter and the value received per $\mathrm{kg}$ of corn ears with husk at $\mathrm{R} \$ 0.74$. Under these conditions, at a dose of $16.4 \mathrm{~mL} \mathrm{~kg}^{-1}$ which resulted in $15,813 \mathrm{~kg}$ ears, the control produced $13,558 \mathrm{~kg}$, resulting in a favorable treatment difference of 2,255 kg. Expenditure on the use of the product was $\mathrm{R} \$ 30$ per hectare and the final profit obtained reached, therefore, $\mathrm{R} \$ 1,638.70$ per hectare with the use of biostimulant.

Based on the results observed in the study, we concluded that the use of biostimulant results in gains in the vegetative and reproductive development of sweet corn. The range of biostimulant doses that allowed positive results varied from 12.4 to $16.4 \mathrm{~mL}$ $\mathrm{kg}^{-1}$. Individually, the responses of the variables to the best dose was $12.4,15.3$, $13.7,12.4,15.7,16.4,15.4$ and $12.5 \mathrm{~mL}$ $\mathrm{kg}^{-1}$, respectively for plant height, first ear insertion height, stem diameter, final population, number of ears per hectare, ear mass with and without straw and ear index. Considering that the ear with straw is the product of sale and therefore the source of economic return to the producer, the dose of $16.4 \mathrm{~mL} \mathrm{~kg}$ is the best indication in this regard.

\section{REFERENCES}

ALBUQUERQUE, CJB; PINHO, RGV; BORGES, ID; SOUZA FILHO, AX; FIORINI, IVA. 2008. Desempenho de híbridos experimentais e comerciais de milho para produção de milho verde. Ciência $e$ Agrotecnologia 32: 768-775.

ÁVILA, MR; BRACCINI, AL; SCAPIM, CA; ALBRECHT, LP; TONIN, TA; STULP, M. 2008. Bioregulator application, agronomic efficiency, and quality of soybean seeds. Scientia Agricola 65: 567-691.

ÁVILA, J; LIMA, SF; VENDRUSCOLO, EP; ALVAREZ, RCF; CONTARDI, LM. 2016. Adubação nitrogenada e uso de bioestimulante em cenoura. Magistra 28: 360-368.

BARBIERI, VHB; LUZ, JMQ; BRITO, CH; DUARTE, JM; GOMES, LS; SANTANA, DG. 2005. Produtividade e rendimento industrial de híbridos de milho doce em função de espaçamento e populações de plantas. Horticultura Brasileira 23: 826-830.

BERTOLIN, DC; SÁ, MED; ARF, O; FURLANI JUNIOR, E; COLOMBO, ADS; CARVALHO, FLBMD. 2010. Aumento da produtividade de soja com a aplicação de bioestimulantes. Bragantia 69: 339-347.

CASTRO, PRC; PEREIRA, MA. 2008. Bioativadores na agricultura. In: GAZZONI, DL (coord). Tiametoxam: uma revolução na agricultura brasileira. Petrópolis: Vozes. p.115-122.

CUNHA, RC; OLIVEIRA, FDA; SOUZA, MDL; MEDEIROS, JF; LIMA, LA; OLIVEIRA, MKT. 2016. Ação de bioestimulante no desenvolvimento inicial do milho doce submetido ao estresse salino. Irriga 1: 191-204.

DAVIÈRE, JM; ACHARD, P. 2013. Gibberellin signaling in plants. Development 140: 11471151.

DOURADO NETO, D; DARIO, GJA; BARBIERI, APP; MARTIN, TN. 2014. Ação de bioestimulante no desempenho agronômico de milho e feijão. Bioscience Journal 30: 371-379.

FAO. 2018. Faostats: Crops. at: http://www.fao. org/faostat/en/\#data/QC. Accessed February 15, 2018.

FERREIRA, LA; OLIVEIRA, JA; PINHO, EVR; QUEIROZ, DL. 2007. Bioestimulante e fertilizante associados ao tratamento de sementes de milho. Revista Brasileira de Sementes 29: 80-89.

GOMES, LS; BRANDÃO, AM; BRITO, CH; MORAES, DF; LOPES, MTG. 2010. Resistência ao acamamento de plantas e ao quebramento do colmo em milho tropical. Pesquisa Agropecuária Brasileira 45: 140145.

GROSSMANN, K. 2010. Auxin herbicides: current status of mechanism and mode of action. Pest Management Science: formerly Pesticide Science 66: 113-120.

HAMAYUN, M; KHAN, SA; KHAN, AL; SHIN, JH; AHMAD, B; SHIN, DH; LEE, IJ. 2010. Exogenous gibberellic acid reprograms soybean to higher growth and salt stress 
tolerance. Journal of agricultural and food chemistry 58: 7226-7232.

JESUS, AA; LIMA, SF; VENDRUSCOLO, EP; ALVAREZ, RCF; CONTARDI, LM. 2016. Análise econômica da produção do milho doce cultivado com aplicação de bioestimulante via semente. Revista de La Facultad de Agronomía 115: 119-127.

KAPPES, C; ANDRADE, JAC; ARF, O; OLIVEIRA, AC; ARF, MV; FERREIRA, JP. 2011. Desempenho de híbridos de milho em diferentes arranjos espaciais de plantas. Bragantia 70: 334-343.

KHAN, AL, WAQAS, M; LEE, IJ. 2015. Resilience of Penicillium resedanum LK6 and exogenous gibberellin in improving Capsicum annuum growth under abiotic stresses. Journal of Plant Research 128: 259-268.

LUZ, JMQ; CAMILO, JS; BARBIERI, VHB; RANGEL, RM; OLIVEIRA, RC. 2014. Produtividade de genótipos de milho doce e milho verde em função de intervalos de colheita. Horticultura Brasileira 32: 163-167.

MAGALHÃES, PC; DURÃES, FOM. 2006. Fisiologia da produção de milho. Sete Lagoas: Embrapa Milho e Sorgo. 10p (circular técnica, 76).

MARTINS, DC; BORGES, ID; CRUZ, JC; NETTO, DAM. 2016. Produtividade de duas cultivares de milho submetidas ao tratamento de sementes com bioestimulantes fertilizantes líquidos e Azospirillum sp. Revista Brasileira de Milho e Sorgo 15: 217-228.

OLIVEIRA, FDA; MEDEIROS, JF; CUNHA, RC; SOUZA, MWL; LIMA, LA. 2016. Uso de bioestimulante como agente amenizador do estresse salino na cultura do milho pipoca. Revista Ciência Agronômica 47: 307-315.

OLIVEIRA JUNIOR, LFG; DELIZA, R.; BRESSAN-SMITH, R; PEREIRA, MG; CHIQUEIRE, TB. 2006. Seleção de genótipos de milho mais promissores para o consumo in natura. Ciência Tecnologia de Alimentos 26: 159-165.

PAZMIÑO, DM; ROMERO-PUERTAS, MC; SANDALIO, LM. 2012. Insights into the toxicity mechanism and cell response to the herbicide 2, 4-D in plants. Plant Signaling \& Behavior 7: 425-427.

PARIZ, CM; ANDREOTTI, M; AZENHA, MV; BERGAMASCHINE, AF; MELO, LMM; LIMA, RC. 2011. Produtividade de grãos de milho e massa seca de braquiárias em consórcio no sistema de integração lavourapecuária. Ciência Rural 41: 875-882.

PEREIRA FILHO, IA; CRUZ, JC; GAMA, EEG. 2003. Cultivares para o consumo verde. In: PEREIRA FILHO (ed). O cultivo do milho verde. Brasília: Embrapa Hortaliças. p.17-30.

RODRIGUES, LA; BATISTA, MS; ALVAREZ, RCF; LIMA, SF; ALVES, CZ. 2015. Avaliação fisiológica de sementes de arroz submetidas a doses de bioestimulante. Nucleus 12: 207-214.

SAKATA, T; ODA, S; TSUNAGA, Y; SHOMURA, H; KAWAGISHI-KOBAYASHI, M; AYA, K; SAKAKIBARA, H. 2014. Reduction of gibberellin by low temperature disrupts pollen development in rice. Plant Physiology 164: 2011-2019.
SCHALLER, GE; BISHOPP, A; KIEBER, JJ. 2015. The yin-yang of hormones: cytokinin and auxin interactions in plant development. Plant Cell 27: 44-63.

SILVA, TTA; PINHO, EVR; CARDOSO, DL; FERREIRA, CA; ALVIM, PO; COSTA, AAF. 2008. Qualidade fisiológica de sementes de milho na presença de bioestimulantes. Ciência e Agrotecnologia 32: 840-846.

SOUZA, EJD; CUNHA, FFD; MAGALHÃES, FF; SILVA, TRD; SANTOS, OFD. 2015. Effect of irrigation and nitrogen fertilization on agronomic traits of sweet corn. Pesquisa Agropecuária Tropical 45: 282-290.

SOUZA, DMG; LOBATO, E. 2004. Cerrado correção do solo e adubação. 2 ed. Brasília: EMBRAPA, 416p.

SOUZA, EJD; CUNHA, FFD; MAGALHÃES, FF; SILVA, TRD; SANTOS, OF. 2016. Eficiência do uso da água pelo milho doce em diferentes lâminas de irrigação e adubação nitrogenada em cobertura. Revista Brasileira de Agricultura Irrigada 10: 750-757.

TAIZ, L;ZEIGER, E; MOLLER, IM; MURPHY, A. 2017. Fisiologia e desenvolvimento vegetal. 6. ed. Porto Alegre, BR: Artmed. 888p.

USDA. United States Department of Agriculture (USDA): Vegetable. 2017. In: http://usda. mannlib.cornell.edu/usda/current/VegeSumm/ VegeSumm-02-22-2017_revision.pdf. Acessado em maio 16, 2017.

VENDRUSCOLO, EP; MARTINS, APB; SELEGUINI, A. 2016. Promoção no desenvolvimento de mudas olerícolas com uso de bioestimulante. Journal of Agronomic Sciences 5: 73-82. 